\title{
MEIE JA TEIE EESTI KIRJAKEEL
}

\author{
KRISTIINA ROSS
}

$\mathrm{E}$ estlaseks olemise juures peetakse tänapäeval üksmeelselt kõige tähtsamaks eesti keelt (Ehala 2017: 171). Üldiselt tugineb rahvuslik identiteet lisaks keelele veel teistelegi ühistunnustele, nagu päritolu, traditsioonid, ajalooline mälu, religioon jms. Siiski on eestlaste jaoks viimased poolteist sajandit just ühine kirjakeel olnud see, mis kõiki rahvusena ühte seob. Järgnevas arutletakse, keda on eesti keele oskamine ja arendamine läbi varasema ajaloo ühte sidunud ning kuidas tekkis kirjakeele ühtsusele tuginev rahvuslik identiteet.

Moodsas mõttes rahvusliku identiteedi alustalaks on ühtne kirjakeel, mis on üsna hiline nähtus ja välja kujunenud ainult õige pisut enne moodsat rahvust ennast. Kirjakeelelise ühtsuse eelloona tuleb aga paratamatult arvestada etnilist identiteeti kindlustanud ühtselt mõistetava kõneldud keele ajaga. Tähendab olukorraga, kus teatud alal elanud inimesed rääkisid mõnevõrra erinevaid, kuid vastastikku enam-vähem mõistetavaid keelevariante. Meie ajaarvamise esimesel aastatuhandel ja teise alguses oli praegune Eesti territoorium arvatavasti üks osa läänemeresoome keelealast, mida Tiit-Rein Viitso on kirjeldanud katkematu murdekontiinumina (Viitso 2008: 11). Selleks et osast murretest kujuneks iseseisev keel, oli vaja nende sisemist integreerumist ning samaaegset eraldumist teistest sugulasmurretest, mida võisid soodustada kontaktid võõraste keeltega. Eesti keel usutakse tekkinuvat vanade hõimumurrete alusel teise aastatuhande esimesel poolel (Rätsep 1989). Igatahes tundub, et selleks ajaks, kui ristisõdijad Eesti ala XIII sajandil vallutama asusid, oli vastastikku enam-vähem mõistetavale keelekasutusele ja teatud ühistele huvidele tuginev eestlaste etniline identiteet juba kujunemisel. Kindlasti ei saa seda samastada XIX sajandi teisel poolel välja arenenud rahvusliku identiteediga, aga Henriku Liivimaa kroonika tunnistab, et mingi ühisnimetaja alla pidid eesti keele kõnelejad vähemasti väljast tulnu silmis juba tol ajal paigutuma. Sest ehkki sageli määratleb Henrik oma kroonikas siinseid elanikke tõesti maakondliku kuuluvuse järgi (sakalased, ugalased, järvalased, virulased jne, vt nt HLV 1982: 198/199), kasutab ta päris tihti ka üldistavat nimetust eestlased (estones) ning eristab selle sõnaga viidatuid liivlastest (lyvones; vt nt HLV 1982: 88/89 jm). See on seda tähelepanuväärsem, et keeleliselt ei saanud eestlased ja liivlased kuigi drastiliselt erineda (Murray 2009: 561-562). Tõsi, Henrik usutakse kirjutanuvat oma kroonika suuresti tagasivaatelisena, aastatel 1224-1227 (Tarvel 1982: 6), mis võis soodustada suuremate üldistuste tegemist, kui jooksvalt sündmusi kajastades oleks olnud loomulik. (Pealegi on kõik säilinud kroonika käsikirjad veelgi hilisemad - vt Tarvel 1982: 10-12.) Kahe rühma, liivlaste ja eestlaste eristamisel võis ristisõdijate poolelt sündmusi kajastanud Henriku jaoks kulgeda oluline eraldusjoon nende vahel, kes varem ja suhteliselt valutult ristiusu vastu võtsid, ja 
nende vahel, kellega asi keerulisemaks osutus. Aga nii või teisiti on selge, et Henriku jaoks moodustasid eestlased üsna tervikliku rühma, mille üheks tunnuseks pidi - eriti Henriku kui tõlgi jaoks - olema nende keel. Kuivõrd eestlaste vaatenurka on kroonikast väga keeruline välja lugeda, siis pole selge, kas ja mil määral eestlased ise end ühtsena nägid. Kroonikas edastatud otseses kõnes paneb Henrik näiteks Viljandi linnuse piiramisel Sakala eestlased endid liivlastele ja lätlastele vastandama, aga pole selge, kui usaldusväärseks niisugust edastust saab pidada, ega seegi, kas tsiteeritud otsekõnes tähendab „meie” kitsalt linnuses olijaid või kõiki eestlasi (Murray 2009: 567). Samas on usutav, et mingi ühistunne pidi erinevaid, kuid vastastikku mõistetavaid eesti murdeid kõnelevatel kohalikel omavahel tekkima, niipea kui nad puutusid kokku kroonikas mainitavaid võõraid keeli (saksa, taani, vene ja läti keelt) kõnelevate inimestega, kellest ilma tõlgi vahenduseta aru ei saadud.

Oli XIII sajandiga, kuidas oli, järgnenud sajanditel domineerisid seisuslikud eristused, mis, tõsi küll, Eesti alal suuresti etniliste ning keeleliste piiridega kattusid: kõrgemate seisuste esindajad kõnelesid saksa (või rootsi) keelt, alamrahvas eesti keelt. Samas kehtis keskajal kõikjal Euroopas keeleline hierarhia, mille tipus valitses ladina keel, mis teised keeled teatud mõttes omavahel võrdsustas. Kiriku ja hariduse keel oli ladina keel, rahvakeeled käibisid eeskätt suulises suhtluses. Väidetavalt iseloomustas n-ö klassikalist keskaega seetõttu keeleline ja rahvuslik sallivus ning rahvuslik ja sellest tulenev keeleline vastasseis hakkas süvenema alles hiliskeskajal ja varauusajal (Kala 2002). Seetõttu ei peeta tõenäoseks, et keskajal võinuks eestlaste etniline eneseteadvus kuigi tugev olla. Keeleteaduse poolt vaadatuna tundub siiski usutav, et mingit rolli pidi mis tahes grupi liikmete keeleoskus keskajalgi eri kogukondade meie-tunde kujunemisel mängima. Ent kuivõrd erinevate sotsiaalsete rühmade omavaheline suhtlus oli piiratud, ei olnud keelteoskus enamiku inimeste jaoks aktuaalne.

Olukord muutus alates XVI sajandist. Ühelt poolt tõi reformatsioon luterlikel aladel kaasa rahvakeelte tormilise arengu. Seni peamiselt suulises suhtluses käibinud keeltele loodi kirjakeeled, sest Martin Luther nõudis, et jumalasõna tuleb õpetada igaühele kõnes ja kirjas tema emakeeles ning Piibel tuleb tõlkida kõigisse rahvakeeltesse (Lepajõe 2013). Sellega kaasnes Eesti oludes eesti keele kui madalaima sotsiaalse kihistuse keele kinnitumine keelehierarhias selgelt kõige alamale positsioonile, kuivõrd rahvakeel, mille maine siinmail reformatsiooni tagajärjel hoogsalt tõusuteele asus, oli ju hoopis kohaliku eliidi omavaheline suhtluskeel - st alguses alam-, hiljem ülemsaksa keel. Vähemalt kirikuelus tõmbas reformatsioon seeläbi eestlaste ja sakslaste vahele varasemast kindlama eraldusjoone ning on koguni kaheldav, kas eestikeelse usulise sõnumi kättesaadavus esimestel reformatsioonijärgsetel aastakümnetel võrreldes katoliku ajaga üldse paraneski (Kala 2017: 59).

Samas jääb vaieldamatuks, et just reformatsiooni mõjul hakati siiski ka eesti kõnekeele baasil looma kirjakeelt. Sealjuures vahetult pärast reformatsiooni, mil eraldusjoon eri rahvuste vahel ei pruukinud veel olla ületamatu, võis eesti kirjakeele arendajate hulgas leiduda ka eesti emakeelega tegelasi. On spekuleeritud, et näiteks esimese osaliselt säilinud eestikeelse raamatu, 1535. aastal ilmunud luterliku katekismuse eesti tõlke autor, Pühavaimu kiriku eesti koguduse pastor Johann Koell võis olla eesti päritolu (Mägiste 
1970: 61). Ja kaheldamatult oli eesti päritolu Pühavaimu kirikuõpetaja kasvandik Hans Susi, kes pandi XVI sajandi keskpaiku perikoope ja kirikulaule eesti keelde tõlkima (Johansen 1935; Masing 1964). Päris kindlasti oli eesti emakeelega inimesi ka nende jesuiitide hulgas või juures, kes XVI sajandi lõpul ja XVII sajandi alguses reformatsiooni tõrjumiseks Lõuna-Eesti aladel hoogsalt kirjakeelt arendasid (Helk 2003: 247, 254-265). Eesti päritolu ja eesti emakeelsust on püütud välja lugeda ka Georg Mülleri saatusest ja tekstidest (Masing 1999), kuid sellele oletusele võib leida ka vastuargumente. Ning vähemasti kõigi hilisemate XVII ja XVIII sajandi eesti kirjakeele arendajate esimeseks keeleks oli juba kindlasti saksa keel, mõnel ka rootsi.

Puht lingvistiliselt kirjakeele ajaloost rääkides ongi eestlaste (ja lätlaste) probleem või eripära teiste Euroopa praeguste rahvastega võrreldes see, et eesti kirjakeele lõid teiskeelsed inimesed. Osa neist olid sündinud siinmail, osa mujal. Näiteks kaks kõige prominentsemat eesti kirjakeele loojatest, esimese grammatika autor ja ühtlasi esimeste suuremate kirjalike tekstimassiivide publitseerija Heinrich Stahl (159?-1657) ning piiblitõlkija Anton Thor Helle (1683-1748) olid sündinud Tallinnas ning tõenäoliselt puutusid vähemalt linnas kõneldud eesti keelega juba noorest peast kokku. Seevastu XVII sajandi teisel veerandil ja keskpaigas tegutsenud jõulise nn barokk-koolkonna esindajad olid kõik sündinud väljaspool Eestit: Georg Salemann (1597-1657), Reiner Brockmann (1609-1647), Johannes Gutslaff (161?-1657), Heinrich Göseken (1612-1681) saksa keelealal, Martin Gilläus (1610-1686) Rootsis. Eestisse tulid nad pärast ülikooliõpinguid ning puutusid eesti keelega esimest korda kokku järelikult alles täiskasvanueas.

Omaette rühma moodustasid siinsete maapastorite kohapeal sündinud pojad, kes n-ö pääsesid löögile XVII sajandi 80-ndatel aastatel tänu tollase Liivimaa kindralsuperintendendi Johann Fischeri toele ja eestkostele. Fischer tuli Saksamaalt Liivimaale (Riiga) kirikujuhiks 1674. aastal ja ise kohalikke keeli ei osanud. Erinevalt Eestimaa konsistooriumi juhtkonnast ja selle hoovuses tegutsenud pastoritest oli Fischer veendunud, et kirjakeele arendamisel ei saa lähtuda õpetatud keelte eeskujust ja abstraktsetest analoogiareeglitest, vaid ülimaks autoriteediks tuleb pidada neid, kes arendatavat keelt emakeelena valdavad. Värvikalt väljendab ta oma seisukohta kirjas Eestimaa konsistooriumile 29. augustil 1687, öeldes: „Sest oletagem, et ma tulen Prantsusmaale keelt õppima ja leian sealt sakslase, kes on 50 aastat seal olnud ja oskab prantsuse keelt, aga tema ja ühe noore prantslase vahel, kes pole peale oma emakeele ühtegi teist keelt kuulnud, tekib tüli, kumb räägib õigesti, kumb valesti. Siis õpetab mind ju mõistus, et ma pean sünnipärast, ehkki noort prantslast selles asjas rohkem uskuma kui vana sakslast. Ja igaüks naeraks viimase välja, kui ta üritaks väita, et Prantsusmaa peab sakslastelt õppima prantsuse keeles rääkima, sellepärast et tema grammatikas olla nii ja nii kirjas." (Fischer 1687; vt ka Piiblikonverentsid 2003: 138; Põldvee 2009: 658). Päriselt emakeelseid noori eestlasi ei olnud XVII sajandi lõpu Eesti- ja Liivimaalt eesti keelt õpetama paraku võtta. Seepärast koondusid Fischeri ideede ümber kohalike maavõi väikelinnapastorite pojad, kes juba lapsepõlvest peale eesti eakaaslastega olid suhelnud: Adrian Virginius, kes oma varast eesti keele oskust ka oma eluloos rõhutab, Johann Hornung ja Bengt Gottfried Forselius. Ehkki kahe esimese kodune lapsepõlvekeel oli saksa keel ja kolmandal tõenäoliselt rootsi 
keel, paistsid nad oma hea eesti keele oskuse poolest silma ning olid selle üle varjamatult uhked. Oma eluloos nimetabki Adrian Virginius ennast ja oma mõttekaaslasi koguni „noorteks eestlasteks”, kirjutades Pilistvere piiblikonverentsi kohta: „Ülejäänud aga, kes eelmisel konverentsil olid olnud, tulid jälle kohale, ja peale selle tuli sinna härra studioosus Johann Hornung, praegune Karula pastor, kes oli minu poolel. Siin läksid nüüd asjad väheke leebemalt kui Liepas ja vanad pastoriisandad jätsid õiguse juba nii mõneski asjas noortele eestlastele (denen jungen Ehsten)." (Virginius 1706)

Vaatamata XVII sajandi lõpu keelereformijate seesugusele enesenimetusele võib arvata, et isegi nemad tajusid end kokku kuuluvat pigem saksa pastorkonnaga kui eestikeelse talurahvaga. Oma enesenimetusega tõmbasid nad lihtsalt piiri endi ja kehvema eesti keele oskusega pastorite vahele. Kõigile tollastele pastoritele oli eesti kirjakeel praktiline tööriist, mida läks vaja oma tööülesannete täitmiseks. Veel XIX sajandi keskel põhjendas Eduard Ahrens, kes oli koostanud esimese soome-orientatsioonilise eesti keele grammatika, oma pühendumust eesti keelele vajadusega täiustada keelt kui vaimuliku tööriista, et selle abil harimatuid eestlasi paremini õigele kristlikule teele juhatada (Vilbaste 1961: 14). Kohalike eesti koguduste vaimulike ametialase identiteedi juurde selle keele oskamine XVI-XVIII sajandil mingil algeliselgi viisil kindlasti kuulus, aga see ei olnud neist enamiku minapildis kuigi esil. Ja kui pietistlike vaadete kohaselt oli talupoegade tegeliku keelepruugi tundmaõppimine pastorile hädavajalik, siis valgustusliku ratsionalismi levides distantseerus vähemalt osa eesti keele arendamisega tegelevatest saksa literaatidest XVIII sajandi teisel poolel oma objektist aina kaugemale. Üleolev suhtumine talupoegade eesti keelde väljendub kõige markantsemalt valgustusliku lingvistika kohalikus musternäidises, Tallinna gümnaasiumi õpetaja ja tollase rektori Friedrich Arveliuse 1792. aastal avaldatud brošüüris „Eesti keele kultuurist”, milles autor kurdab: „Peaaegu iga avalik keskustelu eesti rahva (Nation) teadmistepuudusest ning vaimu ja südame ebapiisavast haritusest, armetust kodusest olukorrast, laiskusest ja puudulikust tööalasest usinusest viib lõpuks välja selleni, et juba selle rahva keel on nii kehv ja kultiveerimata, et sageli tundub lausa võimatu selles paljude asjade kohta käivaid inimlikke kujutelmi rikastada, õigemaks parandada, tundmusi peenendada, ja üleüldse neid inimesi hüvedele vastuvõtlikumaks muuta ning neis suuremat ja tegusamat huvi äratada nende endi tõelise heaolu vastu" (tsiteeritud Undusk 2012: 83 järgi).

Sama didaktilist üleolekut või akadeemilist distantseeritust võib aduda kõigi XIX sajandi saksa literaatide hoiakus, ükskõik kui hinnatava panuse nad eesti keele uurimisse ja arendamisse ka andsid, ehkki romantiliste mõttemudelite tõusmisel valgustuslike kõrvale ning asemele teisenes suhtumine väikekeeltesse olulisel viisil. Nagu palju rõhutatud, oli üheks keskseimaks mõtlejaks, kes aitas äratada huvi erinevate keelte ja rahvaste ning nende mõttemaailmade vastu, Johann Gottfried Herder. Just Herderi ideede levikuga seostatakse ka baltisaksa estofiilide tegevust, sest „Herderi ja ta poolehoidjate mõjul tõstetakse kilbile iga üksiku rahva keele ja kultuuri omapära kui iseväärtus” (Laanekask 1982: 126). „Säärases mõttevoolus muutus rahvuskeel ehk rahvuse emakeel peaaegu pühaks asjaks, maailmavaate intellektuaalseks ja emotsionaalseks hoidjaks - millekski võrratult enamaks kui on tunnetus- 
vahend või reguleeritav instrument" (Undusk 2012: 88). Ometi ei tähendanud huvi tekkimine ja väikekeelte kui eksootiliste uurimisobjektide väärtustamine kaugeltki mitte nende kultuuride võrdsustamist uurijate omakultuuriga ja neid keeli kõnelevate rahvaste tunnustamist võrdsete partneritena. Postkolonialistliku diskursuse argumentatsiooni järgi aitas Herderi mõtteviis, vastupidi, tõmmata n-ö arenenud ja arenemata keelte ja rahvaste vahele just varasemast veelgi sügavama teadliku piiri: „Herder kehtestas põhimõttelise asümmeetria nende vahele, kes kõnelevad lihvitumaid keeli (nagu Herder ja meie) ja on seeläbi võimelised teadma, ning nende vahele, kes lihvimata keelte kõnelejatena on määratud olema need, keda teatakse" (Errington 2008: 55).

Veel XIX sajandi esimesel poolel oli Eestis ja Lätis võimalik te a d a ainult saksa keeles, ehkki teadjates tekkis huvi juba ka läti ja eesti keele ning nendekeelsete mõtteruumide vastu. Keele ühendava või lahutava rolli üle arutledes tasub siinjuures läti ja eesti kirjakeele üldiselt väga paralleelset arengut mööndes meenutada sedagi, mis Joseph Errington ütleb XIX sajandil hoogu kogunud võrdlev-ajaloolise filoloogia kohta tervikuna, käsitledes seda kui „vahendit, mille abil keelelist mitmekesisust rahvusriikide ja impeeriumide maailmas ära kasutada" (Errington 2008: 88). Nimelt oli läti keel saksa taustaga uurijatele huvipakkuv kui vähemalt ositi „oma”, kuivõrd see balti keelena aitas paremini välja joonistada samasse indoeuroopa keelkonda kuuluvate germaani keelte arengulugu. Eesti keel jäi soome-ugri keelena aga eksootiliseks objektiks, mis sai huvi pakkuda ainult „teisena”. Ulrike Plath on eestlaste ja lätlaste „teisestamise” ajalugu kirjeldades uue filoloogilise paradigma kohta nentinud: „Selle konstruktsiooniga tõmmati kultuuriline piir lätlaste ja eestlaste vahele, keda enne vaadeldi koos kas metsikute paganate või hiljem orjadena" (Plath 2008: 51).

Eestlaste ja lätlaste vahele kerkinud uus piir selgitab ilmselt mingil määral sedagi, miks eesti keele kohta ei koostanud baltisaksa uurijad korralikku kaasaegset võrdlev-ajaloolist käsitlust, läti keele kohta aga koostasid. Ferdinand Johann Wiedemann pani küll kokku tänini eesti kirjarahvale eneserikastamisel oluliseks ja tänuväärseks allikaks jäänud sõnaraamatu (1869) ning deskriptiivse grammatika (1875), mille põhjalikkus siiamaani aukartust äratab. Ometi on see ainult kokkukogutud aines, mida autor ei püüdnudki mõtestada, vaid üksnes süstematiseeris, tunnistades oma tööjuubeli sõnavõtus: „Minu osaks langenud soome keeltega pole küll tegeldud nii pikalt ja nii põhjalikult nagu aaria keeltega, mis on sajandite jooksul sadade tublide õpetlaste poolt läbi ja lõhki üksikasjadeni läbi uuritud. See on pigem alles söötis põld, mida on siit ja sealt haritud, sellel põllul tegutsemine ei seisne niivõrd loovas ülesehitavas töös, kuivõrd vaevalises ja tähelepandamatus kogumises, korrastamises ja nähtavale toomises, kuni ehk hilisemate põlvede jaoks on kogunenud küllaldaselt materjali imposantsete ehitiste jaoks." (Wiedemann 2014: 391) Seesuguse „imposantse ehitise” ehk kaasaegse võrdlev-ajaloolise käsitluse oli läti keele tarvis püstitanud teine baltisaksa uurija, August Bielenstein (1826-1907) oma kaheköitelise käsitlusega („Die lettische Sprache, nach ihren Lauten und Formen", 1863-1864), rajades sellega võrdlev-ajaloolise letoloogia eeskätt tänu asjaolule, et nõudlus niisuguse uurimuse järele oli võrdlev-ajaloolises saksa lingvistikas parasjagu väga tungiv. Tõsi küll, keelelisele lähedusele või kaugusele vaatamata nägid mõlemad uuritavas aineses 
eeskätt teaduslikku objekti, ilmutamata kuigivõrd huvi kummagi rahva saatuse vastu. Ent teatud erinevust võib nende poolt üles näidatud leiguse astmes siiski tajuda (ehkki on muidugi raske hinnata, kuipalju see on tingitud kummagi isiksuseomadustest, kuipalju uurimisobjekti keelesugulaslikust kaugusest või lähedusest). Wiedemanni erapooletu kogujaloomus ja kaine asjalikkus tuleb eriti selgelt esile asjaolus, et oma päevikumärkmetes ei maini ta eestlasi peaaegu üldse või kui, siis ainult võimalike informantidena keelenüansside selgitamisel, nagu teisigi mittesakslasi. Nii näiteks pillab ta seoses ühe Lätis-käiguga, et kohtas seal ka mõnda eestlast - sama registreerivalt, nagu ta järgmisel leheküljel konstateerib: „Nägin ka esimesi kurgi” (Wiedemann 2014: 346, 347). Polüglotina suhtus ta eesti keelde lihtsalt kui ühte võimalikku uurimisobjekti kõigi teiste soome-ugri keelte kõrval, keeldudes võtmast eestlaste rahvusliku liikumise suhtes mingitki ideoloogilist seisukohta (Rätsep 2005: 20). Bielensteini hoiakut illustreerivalt tsiteeritakse tihti lõiku tema autobiograafiast: „Meile, Läti Kirjanduse Seltsile, heideti tookord avalikult ette, et me näeme läti rahvas ja tema keeles ainult uurimisobjekti ja pakume oma uuringute tulemusi ainult rahvusvahelisele teadusele ega edenda läti rahva teadmisi, haridust ja vaimset heaolu [---] Pean tunnistama, et mina isiklikult olen tõesti soovinud ennekõike töötada rahvusvahelise teaduse heaks, ehkki ma olen kogu jõust seisnud [ka] selle eest, et meie selts ei kannaks läti sõprade nime (Latviešu draugi) mitte lihtsalt kui tühja silti." (Tsiteeritud Kḷavina 2002 järgi.)

Niisiis, kõigist saksa (ja rootsi) emakeelega haritlastest, kes XVI-XIX sajandil eesti keelt uurisid ja arendasid, pidas võib-olla ainult väike rühm XVII sajandi lõpu mässumeelseid pastoreid, kes end „noorteks eestlasteks” nimetasid, seda keelt kuidagi „omaks”. Kõigile teistele oli see (esialgu) ainult praktiliselt vajalik töövahend või (hiljem ka) põnev teadusliku uurimise objekt.

Seepärast pole ime, et kirikukirjanduse tarbeks loodud kirjakeel oli talupoegade kõneldud keelest üsna erinev. Kirjandusliku etalonkeele ja (liht)rahva kõnekeele suhe on läbi ajaloo olnud vaidluskohaks muidugi kõigi keelte korral: kas eeskuju pakkuv kirjanduskeel peaks olema võimalikult universaalne ja tuginema ratsionaalsetele ning selgetele reeglitele või lähtuma mingi konkreetse paiga keeletarvitusest ning arvestama keele varieerumist ja ebareeglipärasust? Eri aegadel on erinevad keelearendajad olnud neis küsimustes erinevatel seisukohtadel. Saksa keeleteadust innustas XVII sajandil soov kehtestada saksa keel (prantsuse keelega võrdväärse) kõrgkeelena. Aga arusaamad lahknesid selles osas, kui reeglipäraseks ja kunstlikuks kirjakeelt tasub lihvida või kui palju tuleks arvestada mingis kindlas piirkonnas väljakujunenud keelekasutust (Gardt 1999: 128-135). Saksa mõtteruumis käärivad arutlused mõjutasid muidugi ka Eestis tegutsenud keelearendajaid. Asjaolu, et eesti keel oli kõigi selle keelega tegelejate jaoks võõrkeel, kallutas aga lõpptulemust paratamatult selles suunas, et vahe kirjakeele ehk kirikukeele ja kõnekeele ehk talurahva keele vahel oli eriti suur, ilmsesti suurem kui saksa keele enda alal (niipalju kui niisugust vahet üldse kvantitatiivselt hinnata saab). Sealjuures pidasid need, kes eesti kõnekeelt viletsamini tundsid, reeglipärasust ja ühtlasi võimalikult üksühest vastavust saksa keelele kui etalonile ootuspäraselt heaks ja vajalikuks. Need, kes eesti kõnekeelt ja selle variatsioone paremini tundsid, püüdsid kirikukeelt kõnekeelele lähendada. 
Kõigist reformipüüetest hoolimata oli Eduard Ahrens XIX sajandi keskpaiku endiselt sunnitud nentima, et kirikukeel on talupoegade tegelikust kõnepruugist väga erinev. Sealjuures tegi selle muutmise Ahrensi sõnul eriti keeruliseks asjaolu, et eestlased olid selleks ajaks saksapärase keelevariandi ära õppinud ning hindasid seda kõrgelt: „Eestlane ei kuule oma kirikuõpetaja suust muud kui ainult kirikuraamatute vigast keelt ja vastab talle enamasti ka ainult sellessamas keeles, sest ta peab seda haritumaks ja tahab näidata, et ta seda tunneb" (Ahrens 2003b [1853]: 433).

Eestlaste seisukohavõtte ja hinnanguid kirjakeelele pole kirjalikul kujul ja otseses sõnastuses kusagilt võtta. Võib ainult oletada, et XVII sajandi alguse puine ja saksapärane või sajandi keskpaiga barokselt tehislik keel pidi talupoegades võoristust tekitama, sest see polnud paiguti üldse arusaadav. XVII sajandi lõpukümnendi eelpietistide rahvapärastatud keelevariant ning sellele tuginev XVIII sajandi keelevariant, mida kasutati ka ülimalt populaarseks saanud ning laialt levinud pietistlikus lauluraamatus, kujunes aga haritud keele etaloniks. Seepärast pole üllatav, et see sai rahvusliku ärkamise ajal ka inimesi koondava ning innustava ühise kirjakeele aluseks. Igati ootuspäraselt kõlab see vastu köstritütre Lydia Koidula kirjalikust keelepruugist, ehkki oma isa talurahvale suunatud kirjatükkidest võinuks ta õppida ka hoopis teistsugust keelt. Saksapärase pietistliku keele vaimukõrgendavast mainest ja sellele vastanduva rahvapärase stiiliga usutavasti kaasnenud konnotatsioonidest saab võib-olla kõige parema ettekujutuse, võrreldes Otto Wilhelm Masingu ja Friedrich Reinhold Kreutzwaldi valikut rahvapärase ja kirikukeele vahel.

Otto Wilhelm Masing (1763-1832) oli kahtlemata kõige parema, puhtama, ehedama ja eestilikuma eesti keelega kirjamees XIX sajandil (vähemalt enne Jakobsoni). Tema keelt on nii palju ülistatud (vt nt Laanekask 1982), et seda hinnangut pole vaja siinkohal tõestama hakata. Nagu teada, oli ta isa poolt ka geneetiliselt eestlane ning Eduard Ahrens kiidabki tema keeleoskust just rõhudes tema sünnipärasele eestlusele: „[Otto Wilhelm Masingus] tuleb näha sünnipärast eestlast, sest tema isa oli Lohusuu köster ja ta rääkis poisipõlves eesti keelt kui oma emakeelt. Sellele õnnelikule asjaolule võlgnes ta võime veel hiljemgi, mehena, eesti keeles mõtelda." (Ahrens 2003a [1853]: 86-87) Kust Ahrens võtab, et Masing poisipõlves eesti keelt „kui oma emakeelt” rääkis, kui ta ema teatavasti hoopis saksa aadlisoost oli, pole selge. Igatahes Masingu hilisemate positsioonivõttude taustal jääb kahtlaseks, kas ta ise ennast eestlaseks pidas. Päris nii küsimust muidugi püstitada ei saagi, sest XVIII sajandi lõpus ei olnud rahvuslik identiteet sellisena veel kuigi aktuaalne ning „meie” ja „teie” vastandustes mängis olulisemat rolli seisuslik kuuluvus. Ent igal juhul torkab silma, et Masing tõmbab selge piiri iseenda ja oma eestikeelsete tekstide sihtgrupi vahele. Ehtsa valgustajana kirjutab ta oma head mahlakat eesti keelt kõrgemalt positsioonilt kellelegi teisele, madalamale, õpetuseks. See hea mahlakas keel on talurahva ehk „teie / nende” keel. Nii kirjutab ta „Pühapäeva vahelugemiste” „Ees-kõnes” 1818. aastal lugeja poole pöördudes otsesõnu, et ta oleks tahtnud „neile” juba varem kirjutada, aga ei osanud „nende keelt” küllalt hästi:

Agga sest et omma waesust makele polest wägga hästi tundsin, ei sanud mul sedda julgust ollema, et warreminne sulge olleksin ussaldand kättewõtta, enne 
kui te i e [minu sõrendus $-K$. R.] kele olleksin oskand ilma wiggata kirjutada. Ollen siis selle õppimissega kolmkümmend aastad kullutand, egga siiski weel mitte tei e [minu sõrendus $-K$. $R$.] keelt põhjani kätte sanud, et kül murret ollen piddanud. Kui siis selle ramato sees, mis praego teie kätte pakkun, weel mõnda süüd ja wigga kele polest leiate, siis ärge laitke sellepärrast mo nõud, sest ma ollen teinud, mis ollen jõudnud; ja arwan nenda: et se teile kahjuks olleks olnud, kui sedda mis teie heaks ollen püüdnud kirjutada, olleks jänud teie kätte tullemata. (Masing 1818: III)

Friedrich Reinhold Kreutzwald (1803-1883) pidas ennast pärisorjast kingsepa ja toatüdruku pojana kindlasti eestlaseks ja omandas eesti keele kaheldamatult igati emakeelena. XIX sajandi haritlasena vaatas ta hiljem talurahvast muidugi samuti mingis mõttes kõrvalt ja küllap isegi ülevalt, aga tundis end siiski ühena nende ehk eestlaste seas. Nagu kõik tollased eesti keele arendajad, hindas temagi väga kõrgelt Masingu keelt, nimetades Masingut esimeseks, „kes julges üle minna pentsikust ja äpardanud raamatukeelest elava rahvakeele vormide juurde" (Kreutzwald 1959 [1869]: 410). Aga tema enda eesti keel on õigust öelda üsna kehv ja saksapärase lauseehitusega. Saksapärasus ei iseloomusta mitte ainult tema teoreetilisemat laadi arutlusi, kus seda võiks pidada XIX sajandil võib-olla paratamatuseks, vaid ka näiteks „Eesti rahva ennemuistsete juttude” keelt. Kreutzwaldi keele saksapärasuse väljavabandamise ja põhjendamisega oli hädas August Annist, kes püüdis oma käsitluses (Annist 1966) tõestada justnimelt juttude üleüldist rahvapärasust. Võrreldes Kreutzwaldi süntaktilisi erijooni oma analüüsi kirjutamise aegse, st 1960. aastate eesti kirjakeelega, oli Annist sunnitud möönma:

Neidki erinevusi on kokku üsna palju ja just need annavad Kreutzwaldi sõnastusstiilile teatud võõra- ja raskepärase ilme. Kreutzwaldi la u s e gi on suhteliselt palju pikem ja komplitseeritum kui rahval. Tema sõnade järjekorda on raske nimetada rahvapäraseks [---]. Nõnda jääb mõnestki Kreutzwaldi pikast lausest raske, vanamoeline või isegi saksapärane mulje [---]. (Annist 1966: 331)

Eespool Ahrensi sule läbi Masingu eesti keelele antud hinnangut parafraseerides tohib arvata, et Kreutzwald mõtles saksa keeles või vähemalt saksapärastes konstruktsioonides.

Otto Wilhelm Masingu ja Friedrich Reinhold Kreutzwaldi keele võrdlus toob ilmekalt esile, kuidas oma ja võõras eestikeelses mõttemaailmas XIX sajandil väga kummalisel moel sassi läksid või kohad vahetasid. Ennast saksa pastorkonnaga identifitseerinud Masing kasutas justnagu lugejaskonna madaluse ja võõruse rõhutamiseks eriti head ja mahlakat eesti keelt, seevastu ennast ühena esimestest haritlastest eestlasena identifitseerinud Kreutzwald kasutas justnagu iseenda ja lugejaskonna ülendamiseks ja kõrgendamiseks rasket, saksapärast keelt.

Niisiis, ehkki saksa pastorid lõid eesti kirikukeele selleks, et oma õpetust levitada, võtsid eestlased rahvusliku ärkamise ajal selle keele üle ja hakkasid seda omaenda huvides ja õigupoolest sakslaste huvide vastu ära kasutama. Miks see nii läks? Kas see oli eestlaste eriti osav ja kaval kübaratrikk (vanas mustkunstniku viguri tähenduses) või täiesti ootuspärane asjade käik? 
Seda näib olevat kõige kohasem kirjeldada koloniaallingvistika terminites. Mõningate lisaselgitustega saaks siinkohal küllap kasutada enesekolonisatsiooni mõistet, mille tõi Eesti kontekstis käibele Tiit Hennoste (2003: 88-89). Ent veelgi täpsemalt kirjeldab juhtunut Erringtoni juba viidatud raamatus kasutatud kaaperdamise mõiste. Selgub, et eesti kirjakeele kaasus võib küll Euroopa piires tunduda peaaegu unikaalne, kuid laiemas plaanis vastab see nii mõneski mõttes väga hästi koloniaallingvistika praktikatele. Nimelt kirjeldab Errington suahiili ja malai (indoneesia) keele näitel, kuidas belglased ja hollandlased lõid Ida-Aafrika ja Kagu-Aasia rahvastele kirjakeeled selleks, et kehtestada oma kultuuri ja uskumusi, ent sobival hetkel võtsid koloniseeritud kogukonnad n-ö ohjad enda kätte ja hakkasid neile loodud kirjakeeli kasutama oma eesmärkide saavutamiseks, mis olid koloniseerijate huvidele täiesti vastandlikud: „Koloniseeritud kaaperdasid [pirated] 'oma' keeled omaenese eesmärkide saavutamiseks, näidates, kuidas keele õpetamine sarnaneb mõneti informatsiooni või raha jagamisega: kui need on kord juba välja antud, kaotab andja kontrolli nende kasutamise üle" (Errington 2008: 125).

Suahiili ja malai kirjakeele tekkelool on kahtlemata eripärasid, millega eesti kaasuse kirjeldamisel pole midagi peale hakata. Ent lisaks kaaperdamise analoogiale võib nende keelte lugudest leida „meie ja teie kirjakeele” teemat puudutavana muidki ootamatult tuttavaid mustreid. Esiteks muidugi juba seetõttu, et tegemist on kirjakeele loojatele (belglastele ja hollandlastele) võõraste ja kaugete keeltega (mis kuuluvad vastavalt bantu või austroneesia keelte hulka). Aga ootamatu analoogia võib leida sellestki, et ehkki nende keelte emakeelena kõnelejate hulk on (suahiili keelel) alla kümne või (indoneesia keelel) alla kahekümne miljoni, kasutab neid suhtluskeelena vastavalt 80 või 250 miljonit inimest. Postkolonistliku selgituse järgi annab see tunnistust eurooplaste suutlikkusest taandada kohalik keeleline paljusus ühele keelevariandile, mida saab efektiivsemalt kasutada võimu instrumendina (Errington 2008: 16). Suurusjärgud ja proportsioonid on erinevad, aga kirjeldatud muster on ilmsesti rakendatav ka lõunaeesti ja põhjaeesti kirjakeele ajalooliste suhete selgitamisel. Eks olnud ju küsimus kummagi eesti kirjakeele läbilöögivõimest XVII sajandil samuti seotud Liivimaa ja Eestimaa konsistooriumi omavahelise võimuvõitlusega ning lõppkokkuvõttes otsustas põhjaeesti kirjakeele võidu ja selle pealesurumise lõunaeestlastele lihtsalt asjaolu, et kahe asemel ühe keele arendamine oli odavam ja selle abil sai eliit efektiivsemalt oma võimu teostada.

Kirjutise valmimist on toetanud Eesti Teadusagentuuri grant PRG34 „Võimusuhted ja identiteet 16.-18. sajandi eesti kirjakeeles" ja Euroopa Liit Euroopa Regionaalarengu Fondi kaudu (Eesti-uuringute Tippkeskus).

\section{Allikad}

Fischer 1687 = Johann Fischeri kiri Eestimaa konsistooriumile. Rahvusarhiiv, f 1187, n 2, s 371, 1 220-222p. Kai Tafenau käsikirjaline tõlge.

Virginius 1706 = Adrian Virginiuse autobiograafia. Läti Riiklik Ajalooarhiiv, f 214, n 6, s 144a/12, 1 320-340. Kai Tafenau käsikirjaline tõlge. 


\section{Kirjandus}

Ahrens 2003a [1853]. Eesti keele Tallinna murde grammatika. Tlk Kristiina Ross, Kristi Mets, Kristiina Rebane, Mailis Salvet. - Uue ajastu misjonilingvist. Eduard Ahrens 200. Koost ja toim K. Ross. Tallinn: Eesti Keele Sihtasutus, lk $75-429$.

Ahrens 2003b [1853]. Eesti piibli keelevead. Tlk Kristiina Ross. - Uue ajastu misjonilingvist. Eduard Ahrens 200. Koost ja toim K. Ross. Tallinn: Eesti Keele Sihtasutus, lk 430-525.

Annist, August 1966. Friedrich Reinhold Kreutzwaldi muinasjuttude algupära ja kunstiline laad. Eesti NSV Teaduste Akadeemia Keele ja Kirjanduse Instituut. Tallinn: Eesti Raamat.

Eh a la, Martin 2017. Keele rollidest eesti rahvusidentiteedis. - Eesti inimarengu aruanne 2016/2017. Eesti rändeajastul. Toim Tiit Tammaru, Raul Eamets, Kristina Kallas. Tallinn: Eesti Koostöö Kogu, lk 171-178.

Errington, Joseph 2008. Linguistics in a Colonial World. A Story of Language, Meaning, and Power. Oxford: Blackwell Publishing.

Gardt, Andreas 1999. Geschichte der Sprachwissenschaft in Deutschland. Vom Mittelalter bis ins 20. Jahrhundert. Berlin-New York: Walter de Gruyter.

Helk, Vello 2003. Jesuiidid Tartus 1583-1625. Vastureformatsiooni eelpost PõhjaEuroopas. Tlk Kaarel Piirimäe. Tartu: Ilmamaa.

He n n o s te, Tiit 2003. Postkolonialism ja Eesti. Väga väike leksikon. - Vikerkaar, nr 4-5, lk 85-100.

HLV 1982 = Henriku Liivimaa kroonika. Tõlkinud Richard Kleis. Toimetanud ja kommenteerinud Enn Tarvel. Tallinn: Eesti Raamat.

Johan s e n, Paul 1935. Wanradt-Koell'i katekismuse tundmatuist järglastest. Eesti Kirjandus, nr 10, lk 433-436.

Ka la, Tiina 2002. Keeled ja nende kõnelejad keskaegses Tallinnas: edenemine või taandareng? - Tuna, nr 2, lk 8-22.

Kala, Tiina 2017. Eesti keel pärisnimede ja etnonüümide näitel mõnedes varauusaegsetes Tallinna allikates. - Vana Tallinn 28 (32). Tallinn: Tallinna Linnaarhiiv, lk 57-82.

Kl, avin, a, Sarma 2002. Die Werke von August Bielenstein - eine bedeutende Quelle der Indoeuropäistik des 19. Jahrhunderts. http://www.vvk.lv/index. php?sadala=157\&id=371 (7. IX 2018).

Kreutzwald 1959 [1869] = Kiri J. Krohnile 21. märtsil/2. aprillil 1869. - Fr. R. Kreutzwaldi kirjavahetus IV. Kirjad G. Schultz-Bertramile ja teistele 18591874. Tallinn: Eesti Riiklik Kirjastus, lk 407-412.

La a neka sk, Heli 1982. O. W. Masingu keeleteaduslikust vaatepiirist. - Keel ja Kirjandus, nr 3, lk 122-133.

Lepajõe, Marju 2013. Wotzu ist die tzung? Martin Lutheri keele- ja hariduskäsitusest. - Kroonikast kantaadini. Muusade kunstid kesk- ja varauusaegsel Eesti- ja Liivimaal. Koost Katre Kaju. Eesti Ajalooarhiivi toimetised. Acta et commentationes Archivi historici Estoniae 20 (27), lk 69-92.

M a s ing, Otto Wilhelm 1818. Pühhapäwa Wahhe-luggemissed. Essimenne jaggu. Tartu: Schünmanni kirjadega.

Masing, Uku 1964. Hans Susi 1551. a. tõlkest. - Emakeele Seltsi aastaraamat, nr 10, lk 121-136. 
Masing, Uku 1999. Somnium umbrae. - U. Masing, Eesti vanema kirjakeele lood. Tartu: Ilmamaa, lk 135-239; 259-296.

Murray, Alan V. 2009. Eesti keel Henriku kroonikas. Suulisus ja suhtlus XIII sajandi Liivimaa misjonis. - Keel ja Kirjandus, nr 8-9, lk 559-572.

Mägiste, Julius 1970. Vanhin vironkielinen painotuode (vuodelta 1535). J. Mägiste, Vanhan kirjaviron kysymksiä. (Tietolipas 64.) Suomalaisen Kirjallisuuden Seura, lk 52-62.

Piiblikonverentsid 2003 = Piiblikonverentsid ja keelevaidlused. Põhjaeestikeelse Piibli tõlkimise ajaloost (1686-1690). Allikapublikatsioon. Koost Leino Pahtma, Kai Tafenau. Toim Jürgen Beyer. (Ex fontibus archivi historici Estoniae.) Tartu: Eesti Ajalooarhiiv.

Plath, Ulrike 2008. „Euroopa viimased metslased”: eestlased saksa koloniaaldiskursuses 1770-1870. - Rahvuskultuur ja tema teised. (Collegium litterarum 22). Toim Rein Undusk. Tallinn: Underi ja Tuglase Kirjanduskeskus, lk 37-64.

Põldvee, Aivar 2009. Eesti „tähesõja” taust ja retoorika. - Keel ja Kirjandus, nr 8-9, lk 642-667.

Rät s e p, Huno 1989. Eesti keele tekkimise lugu. - Akadeemia, nr 7, lk 1503-1524.

Rät s e p, Huno 2005. Wiedemanni fenomen. - Oma Keel, nr 1, lk 14-20.

T a rve l, Enn 1982. Sissejuhatus. - Henriku Liivimaa kroonika. Tõlkinud Richard Kleis, toimetanud ja kommenteerinud E. Tarvel. Tallinn: Eesti Raamat, lk 5-21. Und u sk, Jaan 2012. Luterlik, valgustuslik ja romantiline keeleideoloogia meie vanemas kirjakultuuris. - Vikerkaar, nr 10-11, lk 73-90.

Vilbaste, Gustav 1961. Eduard Ahrensi katseid eesti kirikukeele parandamiseks. - Emakeele Seltsi aastaraamat XII, lk 11-16.

Viits o, Tiit-Rein 2008. Liivi keel ja läänemeresoome keelemaastikud. Tartu Ülikooli eesti ja üldkeeleteaduse instituut, Eesti Keele Instituut. Tartu-Tallinn: Eesti Keele Sihtasutus.

Wiedemann, Ferdinand Johann 2014. Mälestusi minu elust. Teateid ja ülestähendusi minu sugulaste kohta, kogutud St. Peterburis 1858. aastast alates. Tlk Anti Lääts, toim Jaak Peebo. Tartu: Ilmamaa.

Kristiina Ross (snd 1955), PhD, Eesti Keele Instituudi juhtivteadur (Roosikrantsi 6, 10119 Tallinn), kristiina.ross@eki.ee

\section{Estonian literary language: ours vs yours}

Keywords: history of literary Estonian, colonial linguistics

Estonian national identity is nowadays based on standard literary Estonian. The article discusses which groups of people may have shared the knowledge and development of Estonian earlier in history and what the developers' aims and options were in the $19^{\text {th }}$ century, during the preliminary and early phases of national awakening.

Early modern times was the period of the growth of ethnic and linguistic confrontations underpinning the emergence of natonal self-awareness. For several historico-political and socio-cultural reasons the task of developing written Estonian befell native German (and Swedish) pastors in the $16^{\text {th }}-18^{\text {th }}$ centuries. Their 
Estonian competence varied and their attitudes to the peasant language differed, but even for the most talented of them the language was foreign, not native. As a result, the $19^{\text {th }}$ century witnessed a particularly sharp conflict between the artificial, German-like learned version of Estonian and the vernacular one. The connotations of the two usages can be inferred from a comparison of the linguistic behaviours of Otto Wilhelm Masing and Friedrich Reinhold Kreutzwald. Masing, who identified with German pastorship, emphasised the distance and alienness of his readers by using a particularly vernacular and idiomatic Estonian, whereas Kreutzwald, who was one of the first intellectuals to identify himself as an Estonian, used a heavy, German-like version in order to elevate his readers. The fact that it was the German-like learned Estonian that was chosen to write the texts of the national movement fits well with the colonial linguistic approach by Joseph Errington suggesting that first the colonisers created a written language for their colonised to imbibe the coloniser's culture and religious beliefs, but at an appropriate moment the colonised community would take over and pirate the literary language developed for them, in order to use it for purposes of their own, which were quite the opposite to those of the colonisers.

Kristiina Ross (b. 1955), PhD, Institute of the Estonian Language (Roosikrantsi 6, 10119 Tallinn), Lead Research Fellow, kristiina.ross@eki.ee 